Original Research

\title{
Variations in Carbon, Nitrogen and Phosphorus Stoichiometry during a Growth Season Within a Platycladus orientalis Plantation
}

\author{
Manyi Du ${ }^{1}$, Huanying Feng ${ }^{1}$, Lianjin Zhang ${ }^{1}$, Shunxiang Pei ${ }^{1}$, Di Wu ${ }^{1}$, Xu Gao ${ }^{1}$, \\ Qingyun Kong ${ }^{1}$, Yan Xu ${ }^{1}$, Xuebing Xin ${ }^{1 *}$, Xiaolu Tang ${ }^{2}$ \\ ${ }^{1}$ Experimental Center of Forestry in Northern China, Chinese Academy of Forestry, Beijing, P.R. China \\ ${ }^{2}$ College of Earth Sciences, Chengdu University of Technology, Chengdu, Sichuan, P.R. China
}

Received: 27 November 2019

Accepted: 3 February 2020

\begin{abstract}
Knowledge of seasonal variations of carbon $(\mathrm{C})$, nitrogen $(\mathrm{N})$, and phosphorus $(\mathrm{P})$ concentrations plus C:N:P ratios can provide insight into the dynamics of biological processes, nutrient cycling, resource acquisition, and mass partitioning in plants and soils. Platycladus orientalis (Cupressaceae) is an important tree species distributed throughout northern China. We studied the seasonal dynamics of $\mathrm{C}, \mathrm{N}$, and $\mathrm{P}$ concentrations and their stoichiometry in leaves, branches, roots, and soil in a $P$. orientalis plantation. Plant and soil $\mathrm{C}, \mathrm{N}$, and $\mathrm{P}$ concentrations, and their stoichiometry varied significantly among ecosystem components and growth season sampling times, indicating nutrient allocation patterns and mobility in the $P$. orientalis plantation. Accurately quantifying and comparing C:N:P stoichiometry in the plant and soil of $P$. orientalis requires a study of plant organs, soil depth, and sampling times. The mean $\mathrm{N}$ concentration in leaves was $14.06 \mathrm{~g} \mathrm{~kg}^{-1}$ and the mean $\mathrm{N}: \mathrm{P}$ ratio was 11.82 , indicating that the growth of $P$. orientalis was $\mathrm{N}$ limited during the growing season. $\mathrm{N}$ and $\mathrm{P}$ concentrations and stoichiometry in plants were correlated with those in soil, suggesting coupled nutrient control between plant and soil. The C:N:P ratio was regulated in different components of the ecosystem.
\end{abstract}

Keywords: Platycladus orientalis, C:N:P stoichiometry, plant-soil, nutrient limitation

\section{Introduction}

Carbon $(\mathrm{C})$, nitrogen $(\mathrm{N})$, and phosphorus $(\mathrm{P})$ are primary nutrients that regulate important ecological functions, structures, and processes [1]. Ecological stoichiometry involves the balance of multiple

*e-mail: xinxb01@163.com

chemical elements in an organism and how this shapes ecological interactions [2, 3]. Ecological stoichiometry is important for understanding the adaptive strategies of plants. It provides insight into the relationships between organism and ecosystem structure and the relationship between the C:N:P stoichiometry of a species and its environment [4-6].

Nutrient concentrations in plants reflect nutrient uptake and utilization efficiency during growth. Nutrient concentrations are important in the maintenance 
of plant function and in adaptation to a changing environment [5]. Fast-growing species or fast-growing stages require more $\mathrm{N}$ and $\mathrm{P}$ compared to $\mathrm{C}$, and more $\mathrm{P}$ compared to $\mathrm{N}[2,7]$. The leaf $\mathrm{N}: \mathrm{P}$ ratio is an important index that reflects the shift between $\mathrm{N}$ - and P-limitations [8, 9]. Soil is the main nutrient source for plants. Extractable nutrients in soil regulate plant growth. Studies on ecological stoichiometry and seasonal dynamics of soil $\mathrm{C}, \mathrm{N}$, and $\mathrm{P}$ concentrations reveal the effectiveness and limitations of soil nutrients [10]. The plant-soil feedback mechanism involves the nutrient relationship between plant and soil. It is therefore necessary to study ecological stoichiometry on the whole plant-soil system $[11,12]$.

Nutrient concentrations of plants can vary within and between growing seasons. The resorption of nutrients is essential in supporting spring growth in deciduous species and forbs, which show large seasonal variations in nutrient concentrations. In contrast, evergreen species can retain leaf nutrients and resorption can occur gradually over the growing season $[13,14]$. Some stoichiometry studies have been conducted on plants and soils over a particular season or time period [15-17], but seasonal variations of stoichiometry remain poorly understood. Studying the seasonal dynamics of $\mathrm{C}, \mathrm{N}$, and $\mathrm{P}$ concentrations and their stoichiometry could increase our understanding of nutrient allocation and re-use; further study could also improve forest management, particularly for tree species that grow in ecologically fragile and nutrientlimited areas.

Platycladus orientalis (Cupressaceae) is an evergreen tree species that is highly resistant to cold, drought, and saline-alkaline soil. It is long-lived and well adapted to many different environments. Due to the ability to thrive under a wide range of climate and soil conditions, $P$. orientalis is an important afforestation species. It is widespread throughout China, particularly in ecologically fragile sites and mining areas, and is used for sand stabilization and soil erosion control. Its wood is strong and decay-resistant, making it valuable for building, ship construction, and furniture [1821]. In this study, we hypothesized that $P$. orientalis growth in the Jiulong Mountains is limited by $\mathrm{N}$ or $\mathrm{P}$ in the entire growing season. We also hypothesized that $P$. orientalis and soils would show seasonal variation in their nutrient concentrations and stoichiometric ratios. We determined the $\mathrm{C}, \mathrm{N}$, and $\mathrm{P}$ concentrations as well as the $C: N, C: P$ and $N: P$ ratios of trees and soils in a $P$. orientalis plantation among different stages of a growing season. The specific objectives were to: (1) compare the differences of $\mathrm{C}: \mathrm{N}: \mathrm{P}$ stoichiometry for tree organs, soil, and growth season stage; (2) determine the relationships between stoichiometry between plant organs and soil, and (3) detect the nutrient limitations of $P$. orientalis plantations.

\section{Materials and Methods}

\section{Study Area}

The study area was a $P$. orientalis plantation the Jiulong Mountains (100-997 m altitude, 11559'$\left.116^{\circ} 07^{\prime} \mathrm{E}, 39^{\circ} 54^{\prime}-39^{\circ} 59^{\prime} \mathrm{N}\right)$. This region has a temperate continental monsoon climate. The average annual temperature is $11.8^{\circ} \mathrm{C}$, and the mean annual precipitation is $623 \mathrm{~mm}$. The soil is a brown, rocky mountain forest soil with a high stone content, and the average soil layer thickness ranges from 20 to $50 \mathrm{~cm}$. The forest was planted in 1981 at a density of 3000 trees per hectare. The dominant tree species are $P$. orientalis, Pinus tabulaeformis, and Quercus variabilis [22, 23].

\section{Sample Sampling}

This study was conducted during April 2016. Three plots of $20 \mathrm{~m} \times 20 \mathrm{~m}$ were established in a typical stand that could represent the average state (roughly estimated $\mathrm{DBH}$, tree height, slope) of the $P$. orientalis plantation stand in the study area. Mean diameter at breast height (DBH) was $1.3 \mathrm{~m}$ and height in the inventory plots was $6.6 \mathrm{~cm}$ and $7.3 \mathrm{~m}$. Buds of $P$. orientalis start to burst, and tree growth begins, in mid-April. Trees grow rapidly during July, August, and early September; growth slows in late October. The growth stages of $P$. orientalis were divided into an early growing season (April-June), a fast growing season (July-September), and a late growing season (October).

Plant samples (leaves, branches, and roots) were collected in each plot in the middle of April, June, August, and October 2016. Five standard trees, representing average DBH range, medium size, growth, and crown width, were selected based on the average of the site index of $P$. orientalis. Leaves and branches were sampled from 12 directions of each standard tree using a pole pruner (the directions were the upper, middle, and lower parts of the eastern, southern, western, and northern tree crowns). The sampled leaves and branches were mixed for each plot. Roots were sampled $50 \mathrm{~cm}$ from the base of each standard tree at depths of $0-10$ $\mathrm{cm}$ and 10-20 $\mathrm{cm}$ using $10 \mathrm{~cm}$ diameter soil cores. All visible roots were collected. Leaves, branches, and roots sampled were washed with tap water and oven-dried at $65^{\circ} \mathrm{C}$ to a constant mass. These plant samples were then ground (CT 193 Cyclotec, FOSS, Denmark) and passed through a 10-mesh sieve for $\mathrm{C}, \mathrm{N}$, and $\mathrm{P}$ content analysis [24].

Soil samples were collected at the same times as plant sampling. Soil samples were collected at depths of 0-10 $\mathrm{cm}$ and 10-20 $\mathrm{cm}$ with an $8 \mathrm{~cm}$ diameter hand core after removing mulch from the plot. In each plot, five soil cores of each soil layer were randomly collected and mixed. All soil samples were air-dried and ground (CT 193 Cyclotec, FOSS, Denmark) to a fine powder 
Table 1. Descriptive statistics of C, N, and P concentrations and their stoichiometric ratios for leaves, branches, roots, and soil.

\begin{tabular}{|c|c|c|c|c|c|c|c|}
\hline Element & Items & Mean & Range & Minimum & Maximum & SD & $C V$ \\
\hline \multirow{6}{*}{$\mathrm{C}\left(\mathrm{g} \mathrm{kg}^{-1}\right)$} & Leaves & 446.22 & 32.27 & 431.27 & 463.54 & 10.32 & $2.31 \%$ \\
\hline & Branches & 462.10 & 29.73 & 446.21 & 475.94 & 8.38 & $1.81 \%$ \\
\hline & Roots $(0-10 \mathrm{~cm})$ & 419.19 & 100.65 & 368.69 & 469.34 & 25.48 & $6.08 \%$ \\
\hline & Roots $(10-20 \mathrm{~cm})$ & 417.98 & 96.01 & 369.94 & 465.95 & 30.01 & $7.18 \%$ \\
\hline & Soil $(0-10 \mathrm{~cm})$ & 32.50 & 26.73 & 22.50 & 49.23 & 9.53 & $29.31 \%$ \\
\hline & Soil $(10-20 \mathrm{~cm})$ & 21.00 & 12.04 & 14.25 & 26.29 & 4.05 & $19.30 \%$ \\
\hline \multirow{6}{*}{$\mathrm{N}\left(\mathrm{g} \mathrm{kg}^{-1}\right)$} & Leaves & 14.06 & 5.51 & 10.85 & 16.36 & 1.82 & $12.95 \%$ \\
\hline & Branches & 6.57 & 2.29 & 5.14 & 7.43 & 0.68 & $10.32 \%$ \\
\hline & Roots $(0-10 \mathrm{~cm})$ & 9.38 & 3.91 & 7.65 & 11.56 & 1.16 & $12.40 \%$ \\
\hline & Roots $(10-20 \mathrm{~cm})$ & 8.05 & 4.10 & 6.50 & 10.60 & 1.38 & $17.14 \%$ \\
\hline & Soil $(0-10 \mathrm{~cm})$ & 2.09 & 1.54 & 1.48 & 3.02 & 0.56 & $26.68 \%$ \\
\hline & Soil $(10-20 \mathrm{~cm})$ & 1.78 & 2.01 & 1.01 & 3.02 & 0.53 & $29.88 \%$ \\
\hline \multirow{6}{*}{$\mathrm{P}\left(\mathrm{g} \mathrm{kg}^{-1}\right)$} & Leaves & 1.23 & 1.05 & 0.80 & 1.85 & 0.32 & $26.37 \%$ \\
\hline & Branches & 0.73 & 0.33 & 0.55 & 0.88 & 0.11 & $15.61 \%$ \\
\hline & Roots $(0-10 \mathrm{~cm})$ & 0.40 & 0.33 & 0.22 & 0.55 & 0.09 & $22.31 \%$ \\
\hline & Roots $(10-20 \mathrm{~cm})$ & 0.39 & 0.22 & 0.28 & 0.50 & 0.06 & $16.24 \%$ \\
\hline & Soil $(0-10 \mathrm{~cm})$ & 0.63 & 0.75 & 0.30 & 1.05 & 0.22 & $35.26 \%$ \\
\hline & Soil $(10-20 \mathrm{~cm})$ & 0.59 & 0.54 & 0.26 & 0.80 & 0.18 & $30.51 \%$ \\
\hline \multirow{6}{*}{$\mathrm{C}: \mathrm{N}$} & Leaves & 32.30 & 15.03 & 26.36 & 41.39 & 4.78 & $14.81 \%$ \\
\hline & Branches & 71.12 & 28.85 & 62.76 & 91.61 & 8.53 & $11.99 \%$ \\
\hline & Roots $(0-10 \mathrm{~cm})$ & 45.38 & 21.10 & 34.75 & 55.85 & 6.55 & $14.43 \%$ \\
\hline & Roots $(10-20 \mathrm{~cm})$ & 53.40 & 28.69 & 36.33 & 65.02 & 10.20 & $19.11 \%$ \\
\hline & Soil $(0-10 \mathrm{~cm})$ & 15.52 & 2.98 & 14.10 & 17.08 & 0.98 & $6.29 \%$ \\
\hline & Soil $(10-20 \mathrm{~cm})$ & 14.22 & 1.69 & 13.48 & 15.17 & 0.44 & $3.12 \%$ \\
\hline \multirow{6}{*}{$C: P$} & Leaves & 386.83 & 320.42 & 250.75 & 571.17 & 101.25 & $26.17 \%$ \\
\hline & Branches & 644.85 & 286.26 & 542.19 & 828.45 & 106.42 & $16.50 \%$ \\
\hline & Roots $(0-10 \mathrm{~cm})$ & 1111.90 & 1294.30 & 674.48 & 1968.78 & 328.73 & $29.56 \%$ \\
\hline & Roots $(10-20 \mathrm{~cm})$ & 1086.80 & 860.11 & 776.95 & 1637.06 & 213.01 & $19.60 \%$ \\
\hline & Soil $(0-10 \mathrm{~cm})$ & 55.65 & 61.71 & 35.87 & 97.58 & 18.32 & $32.91 \%$ \\
\hline & Soil $(10-20 \mathrm{~cm})$ & 39.32 & 46.77 & 19.26 & 66.03 & 13.80 & $35.10 \%$ \\
\hline \multirow{6}{*}{$\mathrm{N}: \mathrm{P}$} & Leaves & 11.82 & 6.03 & 8.81 & 14.84 & 1.64 & $13.88 \%$ \\
\hline & Branches & 9.06 & 3.45 & 7.63 & 11.08 & 1.00 & $10.98 \%$ \\
\hline & Roots $(0-10 \mathrm{~cm})$ & 24.37 & 18.29 & 19.22 & 37.51 & 5.26 & $21.58 \%$ \\
\hline & Roots $(10-20 \mathrm{~cm})$ & 20.78 & 14.70 & 16.39 & 31.09 & 4.44 & $21.38 \%$ \\
\hline & Soil $(0-10 \mathrm{~cm})$ & 3.62 & 3.76 & 2.23 & 5.99 & 1.25 & $34.47 \%$ \\
\hline & Soil $(10-20 \mathrm{~cm})$ & 2.77 & 3.27 & 1.37 & 4.64 & 0.99 & $35.64 \%$ \\
\hline
\end{tabular}


(100 mesh sieve) in order to remove gravel and plant remnants for $\mathrm{C}, \mathrm{N}$, and $\mathrm{P}$ content analysis.

\section{Measuring $\mathrm{C}, \mathrm{N}$, and $\mathrm{P}$ Concentrations in Plants and Soil}

The organic carbon (OC) in the plant and the soil samples was analyzed using the $\mathrm{H}_{2} \mathrm{SO}_{4}-\mathrm{K}_{2} \mathrm{Cr}_{2} \mathrm{O}_{7}$ wet oxidation method [25]. Total nitrogen (TN) in the plant and the soil was determined using the Kjeldahl method [24]. Total phosphorus (TP) in the plant and the soil was determined using the $\mathrm{HClO}_{4}-\mathrm{H}_{2} \mathrm{SO}_{4}$ colorimetric method [24]. All data were expressed as mass $\left(\mathrm{g} \mathrm{kg}^{-1}\right) . \mathrm{C}, \mathrm{N}$, and $\mathrm{P}$ stoichiometric ratios of the different samples were calculated as $\mathrm{OC}$ vs. TN (C:N), OC vs. TP (C:P), and TN vs. TP (N:P).

\section{Data Analysis}

All data were tested for homogeneity of variance and, if necessary, log-transformed. Data were then analyzed by the following three steps. First, one-way analysis of variance (ANOVA) and Tukey's post-hoc multiple comparison tests were used to test the significant differences in $\mathrm{C}, \mathrm{N}$, and $\mathrm{P}$ concentrations and $\mathrm{C}: \mathrm{N}: \mathrm{P}$ stoichiometric ratios among plant organs and sampling season and among soil depths and sampling season. Second, a generalized linear model (GLM) was used to assess the effects of plant organs (or soil depths), sampling seasons, and their interactions on plant and soil $\mathrm{C}, \mathrm{N}$, and $\mathrm{P}$ concentrations and $\mathrm{C}: \mathrm{N}: \mathrm{P}$ stoichiometric ratios. The coefficient of variation $(\mathrm{CV})$ was used to describe the degree of variation. Third, Pearson correlation analysis was used to analyze the correlation of $\mathrm{C}: \mathrm{N}: \mathrm{P}$ stoichiometry among plant organs and soil depth. All of the statistical analyses were performed using SPSS (v 19.0, SPSS Inc., Chicago, IL, USA).

\section{Results}

\section{Descriptive Statistics}

Carbon concentrations varied from $14.25 \mathrm{~g} \mathrm{~kg}^{-1}$ (in soil at $10-20 \mathrm{~cm}$ ) to $475.94 \mathrm{~g} \mathrm{~kg}^{-1}$ (in branches) (Table 1). $\mathrm{N}$ concentrations varied from $1.01 \mathrm{~g} \mathrm{~kg}^{-1}$ (in soil at $10-20 \mathrm{~cm}$ ) to $16.36 \mathrm{~g} \mathrm{~kg}^{-1}$ (in leaves), and $\mathrm{P}$ concentrations varied from $0.26 \mathrm{~g} \mathrm{~kg}^{-1}$ (in soil at $10-20 \mathrm{~cm}$ ) to $1.85 \mathrm{~g} \mathrm{~kg}^{-1}$ (in leaves). Mean C concentrations were in the order (high to low) of branches $>$ leaves $>$ roots $(0-10 \mathrm{~cm})>\operatorname{roots}(10-20 \mathrm{~cm})$. The $\mathrm{N}$ concentration order (high to low) was leaves $>$ roots $(0-10 \mathrm{~cm})>$ roots $(10-20 \mathrm{~cm})>$ branches. $\mathrm{P}$ concentrations were the highest in leaves, followed by branches, and $\mathrm{P}$ concentrations in $10-20 \mathrm{~cm}$ roots were the lowest.

Among plant organs, branches had the highest $\mathrm{C}$ concentration $\left(462.10 \mathrm{~g} \mathrm{~kg}^{-1}\right)$ and leaves contained the highest $\mathrm{N}$ and $\mathrm{P}$ concentrations. Leaves had the greatest variation of $\mathrm{N}$ and $\mathrm{P}$ contents, whereas roots at $0-10 \mathrm{~cm}$ had the greatest variation of $\mathrm{C}$ contents. $C V \mathrm{~s}$ of $\mathrm{C}$ contents were low in roots at $10-20 \mathrm{~cm}(<7.18 \%)$ and $29.31 \%$ in soil at $0-10 \mathrm{~cm}$. $C V \mathrm{~s}$ of $\mathrm{N}$ and $\mathrm{P}$ contents varied from $10.32 \%$ to $35.26 \%$.

For stoichiometry, low $\mathrm{P}$ contents and high $\mathrm{C}$ contents led to the highest $\mathrm{C}: \mathrm{P}$ ratios in both plant organs and in soil, ranging from 19.26 (soil at 10-20 cm) to 1968.78 (roots at $0-10 \mathrm{~cm}$ ). C:N and N:P remained at a low level compared to $\mathrm{C}: \mathrm{P}$, changing from 1.37 (soil at $10-20 \mathrm{~cm}$ ) to 91.61 (branches). $C V \mathrm{~s}$ of these ratios also varied greatly, with a low of $3.12 \%$ and a high of $35.64 \%$.
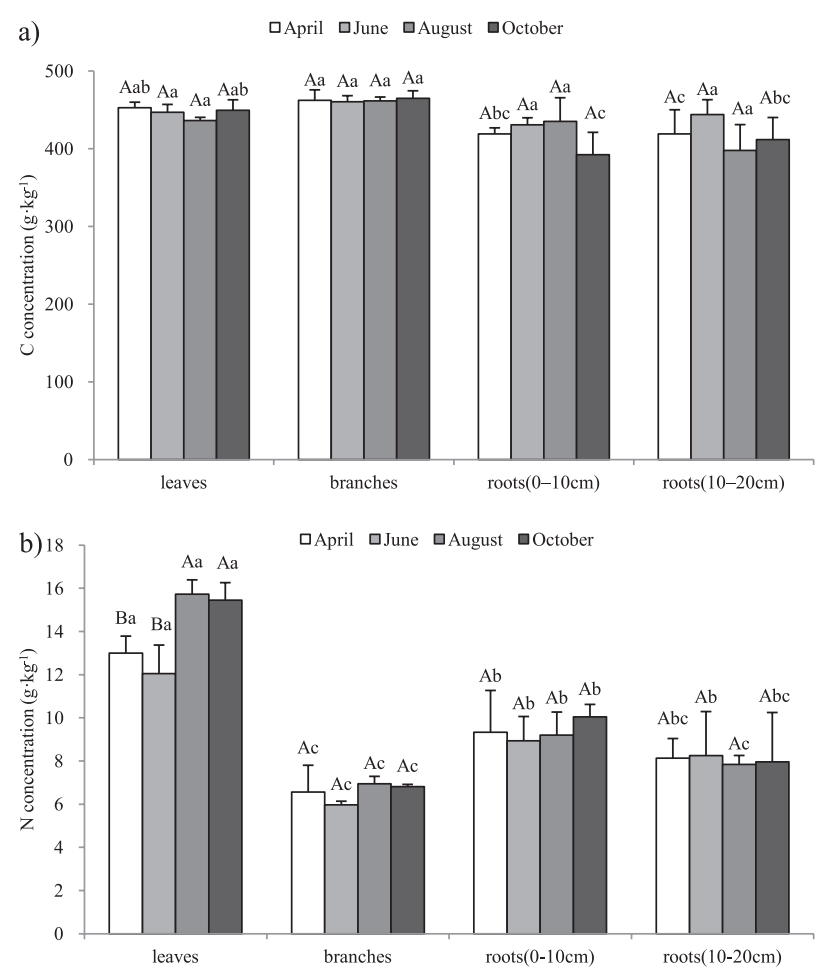

c)

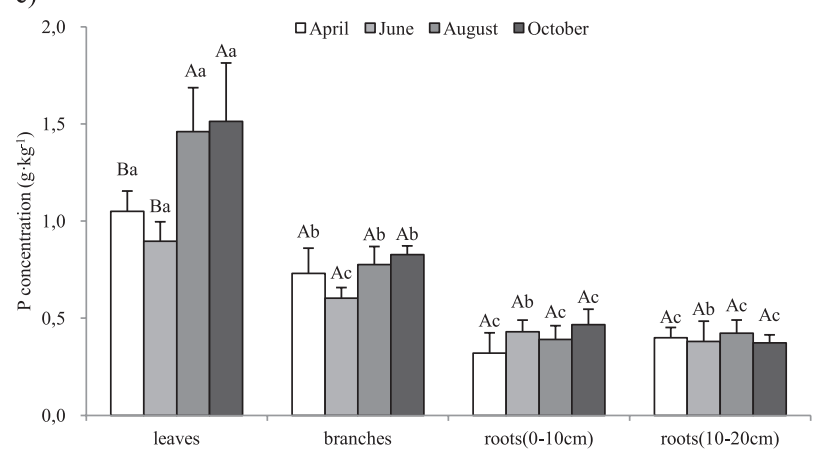

Fig. 1. Seasonal variations of the $\mathrm{C}, \mathrm{N}$, and $\mathrm{P}$ concentrations (mean + standard error) in leaves, branches, and roots: a) seasonal variations of the $\mathrm{C}$ concentration in leaves, branches, and roots; b) Seasonal variations of the $\mathrm{N}$ concentration in leaves, branches, and roots; and c) seasonal variations of the $\mathrm{P}$ concentration in leaves, branches, and roots; different uppercase letters represent significant differences among different sampling seasons at $p<0.05$; different lowercase letters represented significant differences among different organs at $p<0.05$ 


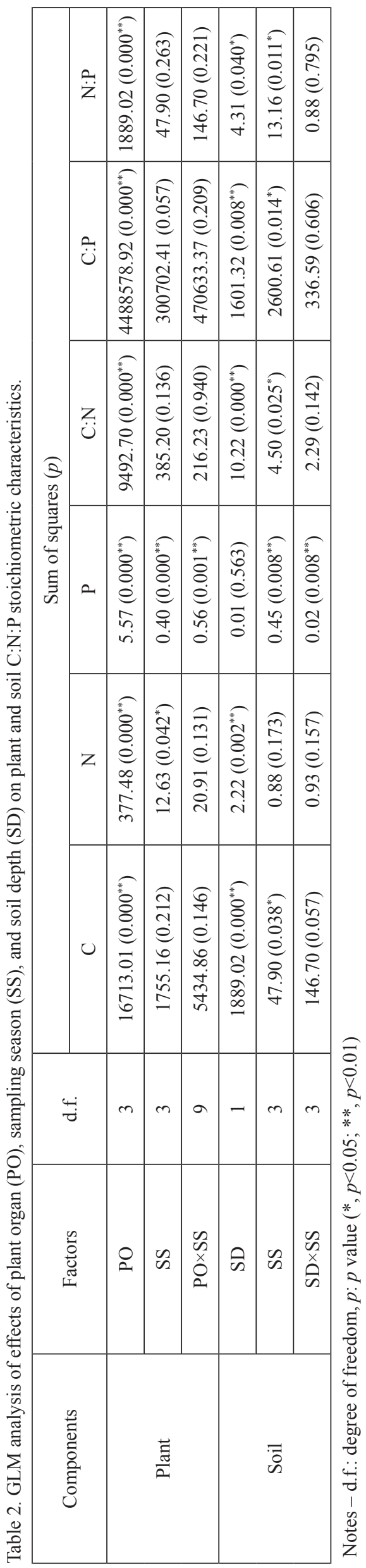

Seasonal Variations of C, N, and P Stoichiometry in Leaves, Branches, and Roots

$\mathrm{C}, \mathrm{N}$, and $\mathrm{P}$ concentrations varied significantly among leaves, branches, and roots $(p<0.05)$. Concentrations in branches were significantly greater than concentrations in roots in April and October, while both $\mathrm{N}$ and $\mathrm{P}$ concentrations of leaves were significantly higher than those of branches and roots. $\mathrm{C}, \mathrm{N}$, and $\mathrm{P}$ concentrations did not vary significantly among seasons in branches and roots, while $\mathrm{N}$ and $\mathrm{P}$ concentrations in leaves differed significantly among growth seasons $(p<0.05)$. Both $\mathrm{N}$ and $\mathrm{P}$ concentrations in leaves were higher in the fast-growing season and lower in the early growing season. Plant organ and
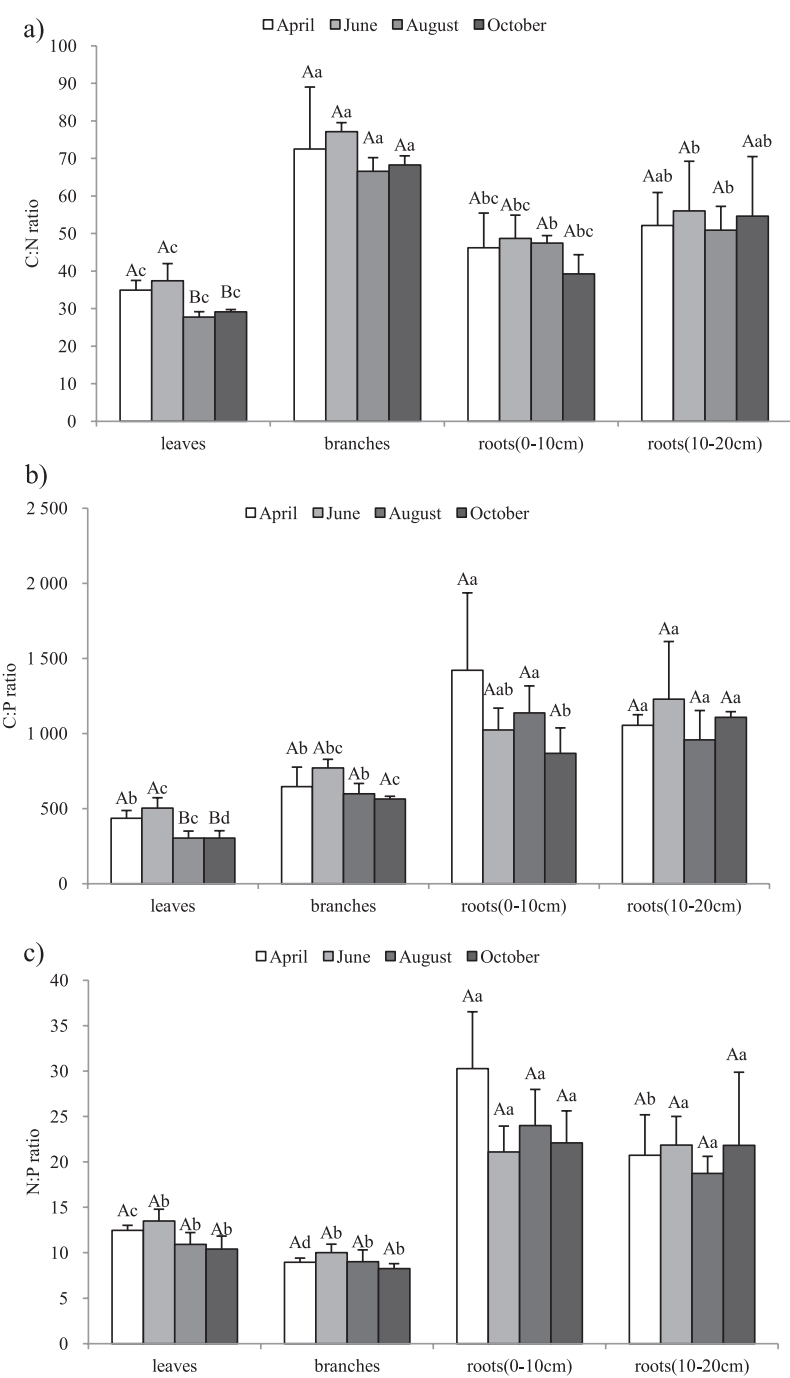

Fig. 2. Seasonal variations of the $\mathrm{C}: \mathrm{N}, \mathrm{C}: \mathrm{P}$ and $\mathrm{N}: \mathrm{P}$ ratios (mean + standard error) in leaves, branches and roots: a) seasonal variations of the $\mathrm{C}: \mathrm{N}$ ratio in leaves, branches and roots; b) Seasonal variations of the C:P ratio concentrations in leaves, branches and roots; and c) seasonal variations of the $\mathrm{N}: \mathrm{P}$ ratio in leaves, branches and roots; different uppercase letters represented significant differences among different sampling seasons at $p<0.05$; different lowercase letters represent significant differences among different organs at $p<0.05$ 
Table 3. Seasonal variations in the $\mathrm{C}, \mathrm{N}$, and $\mathrm{P}$ concentrations and their stoichiometric ratios in different soil depths of $P$. orientalis stands.

\begin{tabular}{|c|c|c|c|c|c|}
\hline \multirow{2}{*}{ Element } & \multirow{2}{*}{$\begin{array}{c}\text { Soil depth } \\
(\mathrm{cm})\end{array}$} & \multicolumn{4}{|c|}{ Sampling seasons } \\
\cline { 2 - 6 } & $0-10$ & $25.45 \pm 3.20 \mathrm{Ca}$ & $27.54 \pm 2.1 \mathrm{BCa}$ & $44.23 \pm 8.07 \mathrm{Aa}$ & $32.77 \pm 10.07 \mathrm{ABCa}$ \\
\hline \multirow{3}{*}{$\mathrm{C}\left(\mathrm{g} \mathrm{kg}^{-1}\right)$} & $10-20$ & $20.99 \pm 4.74 \mathrm{Aa}$ & $21.92 \pm 3.24 \mathrm{Aa}$ & $22.13 \pm 3.64 \mathrm{Ab}$ & $18.97 \pm 5.90 \mathrm{Aa}$ \\
\cline { 2 - 6 } & $0-10$ & $1.75 \pm 0.16 \mathrm{Aa}$ & $1.76 \pm 0.24 \mathrm{Aa}$ & $2.68 \pm 0.44 \mathrm{Aa}$ & $2.15 \pm 0.75 \mathrm{Aa}$ \\
\hline \multirow{2}{*}{$\mathrm{N}\left(\mathrm{g} \mathrm{kg}^{-1}\right)$} & $10-20$ & $1.47 \pm 0.29 \mathrm{Aa}$ & $1.56 \pm 0.23 \mathrm{Aa}$ & $1.52 \pm 0.30 \mathrm{Ab}$ & $1.35 \pm 0.43 \mathrm{Aa}$ \\
\cline { 2 - 6 } & $0-10$ & $0.41 \pm 0.14 \mathrm{Aa}$ & $0.57 \pm 0.11 \mathrm{Aa}$ & $0.72 \pm 0.29 \mathrm{Aa}$ & $0.80 \pm 0.14 \mathrm{Aa}$ \\
\hline \multirow{3}{*}{$\mathrm{P}\left(\mathrm{g} \mathrm{kg}^{-1}\right)$} & $10-20$ & $0.39 \pm 0.16 \mathrm{Aa}$ & $0.60 \pm 0.15 \mathrm{Aa}$ & $0.61 \pm 0.17 \mathrm{Aa}$ & $0.75 \pm 0.04 \mathrm{Aa}$ \\
\cline { 2 - 6 } & $0-10$ & $14.50 \pm 0.55 \mathrm{Aa}$ & $15.80 \pm 1.04 \mathrm{Aa}$ & $16.47 \pm 0.55 \mathrm{Aa}$ & $15.32 \pm 0.68 \mathrm{Aa}$ \\
\hline \multirow{3}{*}{$\mathrm{C}: \mathrm{N}$} & $10-20$ & $14.18 \pm 0.67 \mathrm{Aa}$ & $14.02 \pm 0.19 \mathrm{Ab}$ & $14.59 \pm 0.54 \mathrm{Ab}$ & $14.07 \pm 0.08 \mathrm{Ab}$ \\
\cline { 2 - 6 } & $0-10$ & $65.67 \pm 12.77 \mathrm{Aa}$ & $49.61 \pm 13.40 \mathrm{Aa}$ & $66.6 \pm 27.25 \mathrm{Aa}$ & $40.73 \pm 6.41 \mathrm{Aa}$ \\
\hline \multirow{2}{*}{$\mathrm{C}: \mathrm{P}$} & $10-20$ & $56.56 \pm 9.87 \mathrm{Aa}$ & $37.55 \pm 5.11 \mathrm{Ba}$ & $37.88 \pm 11.42 \mathrm{Ba}$ & $25.27 \pm 6.62 \mathrm{Bb}$ \\
\hline \multirow{2}{*}{$\mathrm{N}: \mathrm{P}$} & $0-10$ & $4.56 \pm 1.03 \mathrm{Aa}$ & $3.17 \pm 1.00 \mathrm{Aa}$ & $4.06 \pm 1.72 \mathrm{Aa}$ & $2.67 \pm 0.53 \mathrm{Aa}$ \\
\cline { 2 - 6 } & $10-20$ & $4.01 \pm 0.78 \mathrm{Aa}$ & $2.67 \pm 0.33 \mathrm{Ba}$ & $2.60 \pm 0.79 \mathrm{Ba}$ & $1.80 \pm 0.48 \mathrm{Ba}$ \\
\hline
\end{tabular}

sampling season interactions significantly affected the $\mathrm{P}$ concentrations. GLM analysis showed that organ type was the largest contributor to the variation in the $\mathrm{C}, \mathrm{N}$, and $\mathrm{P}$ concentrations (Fig. 1, Table 2).

$\mathrm{C}, \mathrm{N}$, and $\mathrm{P}$ stoichiometry varied among leaves, branches, and roots (Fig. 2). For example, C:N ratios of branches were significantly higher than those of leaves and roots $(0-10 \mathrm{~cm})(p<0.05)$, while C:P and $\mathrm{N}: \mathrm{P}$ ratios of roots $(0-10$ and $10-20 \mathrm{~cm})$ differed significantly from leaves and branches. Leaves C:N and C:P significantly differed among seasons $(p<0.05)$. However, the interaction between organ type and season did not affect C:N, C:P and N:P ratios (Table 2).

\section{Seasonal Variations of C, N, and P Stoichiometry in Soil}

Soil C, N, and $\mathrm{P}$ concentrations and their stoichiometric ratios decreased along with soil depth, except for the $\mathrm{P}$ concentrations in June (Table 3). Soil $\mathrm{C}$ and $\mathrm{N}$ concentrations reached a peak in August (both 0-10 $\mathrm{cm}$ and 10-20 cm), while soil $\mathrm{P}$ concentrations reached a peak in October. Similarly, soil C:N and C:P ratios reached a peak in August $(0-10 \mathrm{~cm})$, while soil N:P reached a peak in April (both $0-10 \mathrm{~cm}$ and $10-20 \mathrm{~cm}$ ). GLM analysis showed that soil depth was the greatest contributor to the variation in the $\mathrm{C}$ and $\mathrm{N}$ concentrations, while the sampling season determined the greatest amount of variation in the $\mathrm{P}$ concentration (Table 2).

Soil C, N, and P concentrations and their stoichiometric ratios were significantly affected by soil depth and sampling season individually. However, they were not significantly affected by the interaction effect of soil depth and sampling season, except for $\mathrm{P}$ concentrations. GLM analysis showed that soil depth was the greatest contributor to the variation in the $\mathrm{C}: \mathrm{N}$ ratio, while the sampling season determined the greatest amount of variation in the C:P and N:P ratios (Table 2).

\section{Correlation between Stoichiometry in Plant and Soil}

Most $\mathrm{C}, \mathrm{N}$, and $\mathrm{P}$ stoichiometry among leaves, branches, and roots showed no significant correlations. Only $\mathrm{P}(p<0.05)$ concentrations and C:P $(p<0.01)$ and $\mathrm{N}: \mathrm{P}(p<0.05)$ ratios between leaves and branches were significantly correlated (Table 4).

$\mathrm{N}$ concentrations in leaves were positively correlated $(p<0.05)$ with $\mathrm{N}$ concentrations in the $0-10 \mathrm{~cm}$ depth soil, and the $\mathrm{P}$ concentration in leaves was positively correlated with the $\mathrm{P}$ concentration in the $0-10 \mathrm{~cm}$ and $10-20 \mathrm{~cm}$ depth soil. Soil N and P contents were significantly correlated $(p<0.05)$ with leaves' $\mathrm{N}$ and $\mathrm{P}$ contents, respectively. However, most stoichiometry between plant organs and soil showed no significant correlations. Only the N:P ratio between roots $(10-20 \mathrm{~cm})$ and soil $(0-10 \mathrm{~cm})$ were significantly correlated (Table 4).

\section{Discussion}

\section{C, N, and P Concentrations in Leaves, Branches, and Roots}

C compounds provide the sugars that are the basis for growth, reproduction, and structure, constituting roughly $50 \%$ of plant dry mass [1]. As a supporting and organizing organ, branches are mainly composed of polysaccharides, such as lignin and cellulose, which are rich in carbon [26]. This structural property 
Table 4. Correlation between plant and soil stoichiometry.

\begin{tabular}{|c|c|c|c|c|c|c|}
\hline Element & Items & Leaves & Branches & Roots $(0-10 \mathrm{~cm})$ & Roots $(10-20 \mathrm{~cm})$ & Soil $(0-10 \mathrm{~cm})$ \\
\hline \multirow{5}{*}{$\mathrm{C}\left(\mathrm{g} \mathrm{kg}^{-1}\right)$} & Branches & -0.308 & & & & \\
\hline & Roots $(0-10 \mathrm{~cm})$ & -0.087 & -0.326 & & & \\
\hline & Roots $(10-20 \mathrm{~cm})$ & 0.470 & -0.512 & 0.135 & & \\
\hline & Soil $(0-10 \mathrm{~cm})$ & -0.318 & 0.090 & 0.374 & -0.151 & \\
\hline & Soil $(10-20 \mathrm{~cm})$ & -0.143 & 0.042 & 0.564 & 0.411 & 0.533 \\
\hline \multirow{5}{*}{$\mathrm{N}\left(\mathrm{g} \mathrm{kg}^{-1}\right)$} & Branches & 0.521 & & & & \\
\hline & Roots $(0-10 \mathrm{~cm})$ & 0.101 & -0.528 & & & \\
\hline & Roots $(10-20 \mathrm{~cm})$ & -0.286 & -0.398 & 0.428 & & \\
\hline & Soil $(0-10 \mathrm{~cm})$ & $0.732^{*}$ & 0.406 & -0.141 & -0.224 & \\
\hline & Soil $(10-20 \mathrm{~cm})$ & 0.160 & 0.237 & -0.561 & -0.535 & 0.556 \\
\hline \multirow{5}{*}{$\mathrm{P}\left(\mathrm{g} \mathrm{kg}^{-1}\right)$} & Branches & $0.668^{*}$ & & & & \\
\hline & Roots $(0-10 \mathrm{~cm})$ & 0.291 & -0.133 & & & \\
\hline & Roots $(10-20 \mathrm{~cm})$ & 0.128 & -0.030 & -0.008 & & \\
\hline & Soil $(0-10 \mathrm{~cm})$ & $0.747^{* * *}$ & 0.460 & 0.488 & -0.035 & \\
\hline & Soil $(10-20 \mathrm{~cm})$ & $0.628^{*}$ & 0.511 & 0.427 & -0.038 & $0.771^{* * *}$ \\
\hline \multirow{5}{*}{$\mathrm{C}: \mathrm{N}$} & Branches & 0.442 & & & & \\
\hline & Roots $(0-10 \mathrm{~cm})$ & 0.094 & -0.412 & & & \\
\hline & Roots $(10-20 \mathrm{~cm})$ & -0.066 & -0.409 & 0.508 & & \\
\hline & Soil $(0-10 \mathrm{~cm})$ & -0.321 & -0.216 & 0.017 & -0.007 & \\
\hline & Soil $(10-20 \mathrm{~cm})$ & -0.401 & -0.220 & 0.057 & -0.073 & 0.319 \\
\hline \multirow{5}{*}{$\mathrm{C}: \mathrm{P}$} & Branches & $0.734^{* * *}$ & & & & \\
\hline & Roots $(0-10 \mathrm{~cm})$ & 0.290 & -0.210 & & & \\
\hline & Roots $(10-20 \mathrm{~cm})$ & 0.439 & 0.299 & 0.010 & & \\
\hline & Soil $(0-10 \mathrm{~cm})$ & 0.033 & 0.018 & 0.446 & -0.132 & \\
\hline & Soil $(10-20 \mathrm{~cm})$ & 0.464 & 0.357 & 0.568 & 0.108 & $0.708^{* *}$ \\
\hline \multirow{5}{*}{$\mathrm{N}: \mathrm{P}$} & Branches & $0.653^{*}$ & & & & \\
\hline & Roots $(0-10 \mathrm{~cm})$ & 0.269 & -0.016 & & & \\
\hline & Roots $(10-20 \mathrm{~cm})$ & 0.204 & -0.199 & -0.231 & & \\
\hline & Soil $(0-10 \mathrm{~cm})$ & 0.193 & 0.007 & 0.439 & -0.219 & \\
\hline & Soil $(10-20 \mathrm{~cm})$ & 0.453 & 0.260 & $0.663^{*}$ & -0.041 & $0.764^{* *}$ \\
\hline
\end{tabular}

Notes $-*, p<0.05 ; * *, p<0.01$

determines the highest $\mathrm{C}$ concentration in the branches (462.10 $\mathrm{g} \mathrm{kg}^{-1}$ ) among plant organs (Table 1, Fig. 1). N is an important nutritional element and a fundamental component of all enzymes and chlorophyll in plants [27]. $P$ influences photosynthetic assimilation and biomass production and is a key component of ribonucleic acid (RNA), deoxyribonucleic acid (DNA), and adenosine triphosphate (ATP). P is vital in the storage and translation of genetic information, energy storage, and cell structure [28, 29]. During the growth stage, plants transfer a large amount of nutrients to leaves in order to meet the growth requirements [30], Branches and roots serve as nutrient absorption and transport channels, storing fewer nutrients [31]. Thus, $\mathrm{N}\left(14.06 \mathrm{~g} \mathrm{~kg}^{-1}\right)$ and $\mathrm{P}\left(1.23 \mathrm{~g} \mathrm{~kg}^{-1}\right)$ concentrations were higher in leaves than in branches and roots.

Seasonal variations of nutrients in plant tissues represent a dynamic growth response. These variations may be related to the migration of nutrients caused by changes in the balance between nutrient uptake and 
utilization efficiency [32-35]. $\mathrm{N}$ and $\mathrm{P}$ concentrations in leaves differed significantly with the growing season, showing an initial rise leading to a peak and finally reaching a stable level. Being the main photosynthetic organs, leaves were capable of synthesizing a large number of proteins and nucleic acids [36]. In the early growing season, related to slow leaf growth, cell division was generally slow, requiring fewer proteins and nucleic acids. In the fast-growing season, a large amount of proteins and nucleic acids were needed for the fast growth rate of plants, requiring more $\mathrm{N}$ and $\mathrm{P}$. At the end of the growing season, the leaf growth almost stopped, leading to low $\mathrm{N}$ and $\mathrm{P}$ demands. This result was consistent with previous reports showing that the demand for $\mathrm{N}$ and $\mathrm{P}$ in plants is higher in the fast-growing season than in the slow-growing season [37, 38]. Compared to the rapid increase in leaf biomass, the absorption of nutrients by plants cannot keep up with the rate of cell swelling. Therefore, the nutrients were diluted in various organs, showing a decline in $\mathrm{N}$ and $\mathrm{P}[2$, 39]. However, compared to herbs [40-42], arborvitae trees are a slow-growing species. Thus, $\mathrm{N}$ and $\mathrm{P}$ concentrations were not reduced by the 'dilution effect' of cell division. This phenomenon has also been confirmed in shrubs $[30,43]$ and other coniferous tree species such as larch [44, 45].

\section{Stoichiometry Patterns of C:N:P in Leaves, Branches and Roots}

The stoichiometric characteristics in plant organs at the same developmental stage differed and this was related to the selective absorption and distribution patterns of $\mathrm{C}, \mathrm{N}$, and $\mathrm{P}$. In this study, C:N and C:P ratios in the leaves were the lowest compared to branches and roots, N:P ratios in both leaves and branches were less than 14 , and the N:P ratios in roots $(0-10$ and $10-20 \mathrm{~cm})$ were greater than 20 (Table 1). These results were similar to previous studies finding that structural (rough roots and stems) and metabotropic (leaves, reproductive structure, and fine roots) organs have different functions, resulting in different nutrient contents and stoichiometry [46]. We also found that leaves do not represent the overall nutrient content of the tree. C:N:P stoichiometry was not well-constrained by organs in $P$. orientalis. Therefore, future studies on $P$. orientalis stoichiometry should extend to several different organs such as fine roots.

$\mathrm{CV}$ s indicated that the $\mathrm{C}: \mathrm{N}$ ratios were more stable than $\mathrm{C}: \mathrm{P}$ and $\mathrm{N}: \mathrm{P}$ ratios during the growing season (Table 1, Fig. 2). The C:N, C:P and N:P ratios in leaves increased first and then decreased along with further growth. The highest $\mathrm{C}: \mathrm{N}, \mathrm{C}: \mathrm{P}$ and $\mathrm{N}: \mathrm{P}$ ratios in leaves occurred in the early growing season, and the lowest ratios in the fast-growing and the late-growing seasons. This may be related to soil $\mathrm{N}$ and $\mathrm{P}$ concentrations, which were higher in August and October and lower in April and June (Table 3). Generally, both C:N and
C:P stoichiometry can be used to estimate $\mathrm{N}$-use efficiency and P-use efficiency. High C:N and C:P ratios represented high utilization rates of $\mathrm{N}$ and $\mathrm{P}$, but low plant growth rates [36, 47]. In the case of a shortage of nutrient elements, plants often have a higher nutrient use efficiency and resorption efficiency. This is a survival strategy for plants in barren environment conditions $[16,35,48]$. In this study, $P$. orientalis was more prone to nutrient limitation and shortage in the early growing season. Therefore, it was possible for plants to satisfy nutrient needs by increasing the efficiency of $\mathrm{N}$ and $\mathrm{P}$ utilization.

The leaf N:P ratio was an indicator of the relative limitation of N vs. P. plant growth, limited by concurrent $\mathrm{N}$ concentrations $<20 \mathrm{~g} \mathrm{~kg}^{-1}$ and $\mathrm{N}: \mathrm{P}$ ratios $<14$, whereas $\mathrm{P}$ concentration $<1 \mathrm{~g} \mathrm{~kg}^{-1}$ and $\mathrm{N}: \mathrm{P}$ ratio $>16$ often signify $\mathrm{P}$ limitation $[8,49]$. In this study, the average leaf N:P ratio was 11.82 , and the average $\mathrm{N}$ concentration was $14.06 \mathrm{~g} \mathrm{~kg}^{-1}$. This indicated that $P$. orientalis in the rocky mountainous area of northern China is more restricted by $\mathrm{N}$ elements during the whole growing season. The $\mathrm{N}$ limitation threshold varies in interspecific ecosystems and growing sites [29, 50]. A more robust evaluation of nutrient limitations within an ecosystem involves nutrient inputs and fertilization experiments [51].

\section{Soil C, N, and P Concentrations}

Soil depth significantly affected the $\mathrm{C}$ and $\mathrm{N}$ concentrations in $P$. orientalis soil. $\mathrm{C}$ and $\mathrm{N}$ concentrations in $0-10 \mathrm{~cm}$-deep soil were higher than those in $10-20 \mathrm{~cm}$ soil. The results of this study were similar to those of previously published information [41]. Leaves, branches, and harvest residues were deposited on the surface layer of soil and then the humus formed after decomposition accumulated in the upper soil $[52,53]$. P concentration was mainly affected by the weathering of soil parent materials. Rock weathering is a long process [54], and $\mathrm{P}$ concentrations in soil showed no significant difference between soil layers.

Sampling season significantly affected soil $\mathrm{C}$ and $\mathrm{P}$ concentrations in $P$. orientalis. This is consistent with the results of other studies $[55,56]$. Soil $\mathrm{C}$ and $\mathrm{P}$ concentrations of $P$. orientalis peaked in August because the increased microbial activity at higher temperatures favored the capacity of the system to utilize nutrients or organic materials. As a result, nutrients and organic materials may enter the soil [57].

\section{Soil C:N:P Stoichiometry}

Soil stoichiometry showed significant differences between soil depths. C:N, C:P, and N:P ratios of the $0-10 \mathrm{~cm}$ soil layer were higher than those in $10-20 \mathrm{~cm}$ soil layer. This result was similar to results of a previous study [58] showing that the $\mathrm{C}: \mathrm{N}, \mathrm{C}: \mathrm{P}$, and $\mathrm{N}: \mathrm{P}$ ratios of the organic-rich soil layer $(0-10 \mathrm{~cm})$ were significantly higher than those in total soil depths. This was the result of relatively stable soil $\mathrm{P}$ content throughout the 
soil profile compared to the rapid decline in $\mathrm{C}$ and $\mathrm{N}$ along with soil depth.

Sampling seasons had a significant effect on soil stoichiometry. The $\mathrm{C}: \mathrm{N}$ ratio was more stable than $\mathrm{C}: \mathrm{P}$ and N:P ratios during the whole growing season. Plants are the major source of total soil $\mathrm{C}$ and $\mathrm{N}$ in terrestrial systems, and the biogeochemical cycles of $\mathrm{C}$ and $\mathrm{N}$ are tightly coupled in terrestrial ecosystems, requiring a relative fixation ratio of carbon $[59,60]$. Soil C:P and $\mathrm{N}: \mathrm{P}$ ratios of $10-20 \mathrm{~cm}$ peaked in April, which was due to the low soil $\mathrm{P}$ concentration in April.

The soil N:P ratio can be used as a diagnostic indicator of $\mathrm{N}$ saturation and to determine the threshold for nutrient limitation [52]. The average soil N:P ratio in the study was $2.77-3.62$, which is lower than the average of China (9.3) and the global average (13.1) [61]. The low soil N:P ratio in our study area indicates a high possibility of soil $\mathrm{N}$ deficiency.

\section{Correlation between Plant and Soil Stoichiometry}

$\mathrm{P}$ concentration, $\mathrm{C}: \mathrm{P}$, and $\mathrm{N}: \mathrm{P}$ ratios in leaves and branches were significantly positively correlated (Table 4), indicating that nutrient use efficiency was similar between leaves and branches. This study was similar to an earlier study [62] that found that significant correlations of $\mathrm{C}, \mathrm{N}$, and $\mathrm{P}$ concentrations among organs mainly occurred in the above-ground parts of Vitex rotundifolia, especially between twigs and creeping stems. This study also confirmed previous results [38] showing that the C:P ratio in leaves and branches had a significant positive correlation. The branches and leaves collected in this study were located on the same branch. Since the branches were the most adjacent nutrient transport channels to leaves, the extraction and absorption of nutrients in branches and leaves were synchronized. This could explain the significantly positive correlation between $\mathrm{P}$ concentration, C:P, and $\mathrm{N}: \mathrm{P}$ ratios in leaves and branches.

$\mathrm{N}$ and $\mathrm{P}$ concentrations in leaves were significantly positively correlated with soil $\mathrm{N}$ and $\mathrm{P}$ concentrations, respectively. Similarly, N:P in $10-20 \mathrm{~cm}$ roots was significantly positively correlated with the N:P in $0-10 \mathrm{~cm}$ soil (Table 4). These data confirmed the results of previous studies. For example, $\mathrm{N}$ and $\mathrm{P}$ concentrations in plants were positively correlated with soil $\mathrm{N}$ and $\mathrm{P}$ concentrations in an evergreen broad-leaved forest in Southwest China [63]. Leaf P concentrations and the $\mathrm{N}: \mathrm{P}$ ratio of plant leaves were significantly correlated with soil $\mathrm{P}$ levels in a P-enriched area of the Lake Dianchi watershed in southwestern China [64]. These results also indicate that soil nutrient concentrations are coupled with plant nutrient concentrations [63, 64]. In this study, leaf nutrient concentrations were highly related to soil nutrient concentrations, but this did not indicate that a stable relationship exists in the stoichiometric ratios between the leaves and soil (Table 4). This result confirmed previous studies [32]. Plants absorb nutrients from the soil and have a significant allometric growth relationship between the absorption of $\mathrm{N}$ and $\mathrm{P}$ in leaves [65]. However, the restriction of $\mathrm{N}$ or $\mathrm{P}$ elements in soil may alter this allometric relationship [38]. In fact, we found that $P$. orientalis was limited by $\mathrm{N}$ elements during the entire growing season.

Soil is the main nutrient source for plant photosynthesis and growth and plants return some nutrients back to the soil in the form of litter and its decomposition products [66, 67]. Therefore, C, N, and $\mathrm{P}$ concentrations of the vegetation and soil are significantly correlated [68]. The C:N:P ratio was regulated in different components of the ecosystem [69], and our study mainly focused on the system transfer processes of how $\mathrm{C}: \mathrm{N}: \mathrm{P}$ varied from low $\mathrm{C}: \mathrm{N}$ and C:P (soil) to high $\mathrm{C}: \mathrm{N}$ and $\mathrm{C}: \mathrm{P}$ (leaves, branches, and roots). In the karst area of northwestern Guangxi [70], the Loess Plateau [71], and subtropical China [72], the $\mathrm{C}: \mathrm{N}, \mathrm{C}: \mathrm{P}$, and $\mathrm{N}: \mathrm{P}$ values of the forest soil were lower than those in plants, which is consistent with the present study.

\section{Conclusions}

Seasonal variations in $\mathrm{C}, \mathrm{N}$, and $\mathrm{P}$ concentrations and their stoichiometric ratios were studied in a $P$. orientalis plantation. The results reflect the physiological and nutritional demands of these trees and mirror the specific geographic environment. We found that:

(1) Plant organs, soil depths, and sampling seasons need to be included when quantifying and comparing $\mathrm{C}: \mathrm{N}: \mathrm{P}$ stoichiometry in both plants and soil in $P$. orientalis plantations. Organ type was the largest contributor to the variations in the $\mathrm{C}, \mathrm{N}$, and $\mathrm{P}$ concentrations and $\mathrm{C}: \mathrm{N}: \mathrm{P}$ stoichiometry of trees. Soil depth was the largest contributor to the variations in the $\mathrm{C}, \mathrm{N}$ concentrations and $\mathrm{C}: \mathrm{N}$ ratio. Sampling time contributed the greatest amount of variation in the $\mathrm{P}$ concentration, $\mathrm{C}: \mathrm{P}$ and $\mathrm{N}: \mathrm{P}$ ratios. In both trees and soil, the $C: N$ ratios were more stable than $C: P$ and $N: P$ ratios during the growing season.

(2) Significant variations among $\mathrm{C}, \mathrm{N}$, and $\mathrm{P}$ concentrations or $\mathrm{C}: \mathrm{N}, \mathrm{C}: \mathrm{P}$ and $\mathrm{N}: \mathrm{P}$ ratios were observed among leaves, branches, and roots during the stages of the growing season, indicating patterns of nutrient allocation and mobility.

(3) $\mathrm{N}$ concentration in leaves was $14.06 \mathrm{~g} \mathrm{~kg}^{-1}$, and the N:P ratio was 11.82, indicating a $\mathrm{N}$ limitation in $P$. orientalis during stages of the growing season - especially in the early growing season stage. This offers insight into the fertilizer requirements of forested ecosystems.

(4) Significant correlation between the $\mathrm{N}$ and $\mathrm{P}$ concentrations of leaves and soil $\mathrm{N}$ and $\mathrm{P}$ concentrations suggested the coupled mobility or control between plant and soil, and the C:N:P ratio was regulated in different components of the ecosystem. 
In summary, ecological chemometric studies in $P$. orientalis can refine population stoichiometry. These results are applicable to the sustainable management of $P$. orientalis plantations and provide a scientific procedure for soil nutrient diagnosis and data for enabling of large-scale ecosystem chemometrics study and transformation.

\section{Acknowledgements}

This work was supported by the Fundamental Research Funds for the Central Nonprofit Research Institution of CAF (grant Nos. CAFYBB2014QA036 and CAFYBB2018GC010) and the National Key Research and Development Program of China (grant No. 2016YFD060020304).

\section{Conflicts of Interest}

The authors declare no conflict of interest.

\section{References}

1. YANG X.J., HUANG Z.Y., ZHANG K.L., CORNELISSEN J.H.C. C:N:P stoichiometry of Artemisia species and close relatives across northern China: unravelling effects of climate, soil and taxonomy. Journal of Ecology 103 (4), 1020, 2015.

2. ÅGREN G.I. Stoichiometry and nutrition of plant growth in natural communities. Annual review of ecology, evolution, and systematics 39, 153, 2008.

3. ELSER J.J., STERNER R.W., GOROKHOVA E., FAGAN W.F., MARKOW T., COTNER J.B., HARRISON J., HOBBIE S.E., ODELL G.M., WEIDER L.J. Biological stoichiometry from genes to ecosystems. Ecology Letters 3, 540, 2000.

4. SARDANS J., RIVAS-UBACH A., PEÑUELAS J. The $\mathrm{C}$ : N: P stoichiometry of organisms and ecosystems in a changing world: a review and perspectives. Perspectives in Plant Ecology, Evolution and Systematics 14, 33, 2012.

5. YANG Y.H., LUO Y.Q. Carbon: nitrogen stoichiometry in forest ecosystems during stand development. Global Ecology and Biogeography 20, 354, 2011.

6. XIA C.X., YU D., WANG Z., XIE D. Stoichiometry patterns of leaf carbon, nitrogen and phosphorous in aquatic macrophytes in eastern China. Ecological Engineering 70, 406, 2014.

7. ELSER J.J., FAGAN W.F., KERKHOFF A.J., SWENSON N.G., ENQUIST B.J. Biological stoichiometry of plant production: metabolism, scaling and ecological response to global change. New Phytologist 186, 593, 2010.

8. KOERSELMAN W., MEULEMAN A.F.M. The vegetation N: P ratio: a new tool to detect the nature of nutrient limitation. Journal of Applied Ecology 33, 1441, 1996.

9. ZHAO W.Q., REICH P B.P., YU Q.N., ZHAO N., YIN C.Y., ZHAO C.Z., LI D.D, HU J., LI T., YIN H.J., LIU Q. Shrub type dominates the vertical distribution of leaf $\mathrm{C}: \mathrm{N}: \mathrm{P}$ stoichiometry across an extensive altitudinal gradient. Biogeosciences Discussions 15, 2032, 2018.
10. YANG D.X., SONG L., JIN G.Z. The soil C:N:P stoichiometry is more sensitive than the leaf $\mathrm{C}: \mathrm{N}: \mathrm{P}$ stoichiometry to nitrogen addition: a four-year nitrogen addition experiment in a Pinus koraiensis plantation. Plant and Soil 442, 183, 2019.

11. HONG J.T., WU J.B., WANG X.D. Effects of global climate change on the $\mathrm{C}, \mathrm{N}$, and $\mathrm{P}$ stoichiometry of terrestrial plants. Chinese Journal of Applied Ecology 24 (9), 2658, 2013.

12. NIE L.Q., WU Q., YAO B., FU S., HU Q.W. Leaf litter and soil carbon, nitrogen, and phosphorus stoichiometry of dominant plant species in the Poyang Lake wetland. Acta Ecologica Sinica 36 (7), 1898, 2016.

13. SARDANS J., RIVAS-UBACH A., PEÑUELAS J. Factors affecting nutrient concentration and stoichiometry of forest trees in Catalonia (NE Spain). Forest Ecology and Management 262, 2024, 2011.

14. KERKHOFF A.J., ENQUIST B.J., ELSER J.J., FAGAN W.F. Plant allometry, stoichiometry and the temperaturedependence of primary productivity. Global Ecology and Biogeography 14, 585, 2005.

15. TIAN L.M., ZHAO L., WU X.D., FANG H.B., ZHAO Y.H., HU G.J., YUE G.Y., SHENG Y., WU J.C., CHEN J. Soil moisture and texture primarily control the soil nutrient stoichiometry across the Tibetan grassland. Science of the Total Environment 622-623, 192, 2017.

16. WRIGHT I.J., REICH P.B., WESTOBY M., ACKERLY D.D., BARUCH Z., BONGERS F., CAVENDER-BARES J., CHAPIN T., CORNELISSEN J.H.C., DIEMER M., FLEXAS J., GARNIER E., GROOM P.K., GULIAS J., HIKOSAKA K., LAMONT B.B., LEE T., LEE W., LUSK C., MIDGLEY J.J., NAVAS M.L., NIINEMETS Ü., OLEKSYN J., OSADA N., POORTER H., POOT P., PRIOR L., PYANKOV V.I., ROUMTE C., THOMAS S.C., TJOELKER M.G., VENEKLAAS E.J., VILLAR R. The worldwide leaf economics spectrum. Nature 428, 821, 2004.

17. FAN H.B., WU J.P., LIU W.F., YUAN Y.H., HU L., CAI Q.K. Linkages of plant and soil C:N:P stoichiometry and their relationships to forest growth in subtropical plantations. Plant and Soil 392, 127, 2015.

18. CHANG E.M., SHI S.Q, LIU J.F., CHENG T.L., XUE L., YANG X.Y., YANG W.J., LAN Q., JIANG Z.P. Selection of reference genes for quantitative geneexpression studies in Platycladus orientalis (Cupressaceae) using real-time PCR. Plos one 7 (3), e33278, 2012.

19. ZHOU F.R., WANG J.X., YANG N. Growth responses, antioxidant enzyme activities and lead accumulation of Sophora japonica and Platycladus orientalis seedlings under $\mathrm{Pb}$ and water stress. Plant Growth Regulation 75, 383, 2015

20. ZHU L., LOU A.R. Old-growth Platycladus orientalis as a resource for reproductive capacity and genetic diversity. Plos one 8 (2), e56489, 2013.

21. HU X.G., JIN Y.Q., WANG X.R., MAO J.F., LI Y. Predicting impacts of future climate change on the distribution of the widespread conifer Platycladus orientalis. Plos one 10 (7), e0132326, 2015.

22. ZHANG L.J., HUI G.Y., HU Y.B., ZHAO Z.H. Spatial structural characteristics of forests dominated by Pinus tabulaeformis Carr. Plos one 13 (4), e0194710, 2018.

23. DU M.Y., FENG H.Y., ZHANG, L.J., PEI S.X., XIN X.B., KONG Q.Y., SUN L.F., SUN C.Z. Soil carbon and nitrogen characteristics in different vegetation restoration types in the lithoid hilly are of Northern China. Chinese Journal of Ecology 37 (6), 1849, 2018. 
24. BAO S.D. Soil and agricultural chemistry analysis. China Agriculture Press, 2000, Beijing.

25. FAN S.H., GUAN F.Y., XU X.L., FORRESTER D.I., MA W., TANG X.L. Ecosystem Carbon Stock Loss after Land Use Change in Subtropical Forests in China. Forests 7, 142, 2016.

26. FREUDENBERG K., NEISH A.C. Constitution and biosynthesis of lignin. Springer-Verlag. 1968, BerlinHeidelberg-New York.

27. CHEN Y.H., HAN W.X., TANG. L., TANG Z.Y., FANG J.Y. Leaf nitrogen and phosphorus concentrations of woody plants differ in responses to climate, soil and plant growth form. Ecography 36, 178, 2013.

28. ÅGREN G.I., WETTERSTEDT J.Å.M., BILLBERGER M.F.K. Nutrient limitation on terrestrial plant growth modeling the interaction between nitrogen and phosphorus. New Phytologist 194, 953, 2012.

29. DU M.Y., FAN S.H., LIU G.L., FENG H.Y., GUO B.H., TANG X.L. Stoichiometric characteristics of carbon, nitrogen and phosphorus in Phyllostachys edulis forests of China. Chinese Journal of Plant Ecology 40 (8), 760, 2016.

30. REN Y.T., ZHANG C.X., SHANG Z.Y., HE L., WU S.J., ZHANG B.L., LI J.B., FU H., NIU D.C. Seasonal variation of leaf traits of five eremophyte species in the Alxa Desert. Arid Zone Research 34 (4), 823, 2017.

31. HEINEMAN K.D., TURNER B.L., DALLING J.W. Variation in wood nutrients along a tropical soil fertility gradient. New Phytologist 211, 440, 2016.

32. YANG L.X., WANG Y.L., HUANG J.Y., ZHU J.G., YANG H.J., LIU G.Q., LIU H.J., DONG G.C., HU J. Seasonal changes in the effects of free-air $\mathrm{CO}_{2}$ enrichment (FACE) on phosphorus uptake and utilization of rice at three levels of nitrogen fertilization. Field Crops Research 102, 141, 2007.

33. PING C., WANG C.K., QUAN X.K. Influence of environmental changes on stoichiometric traits of nitrogen and phosphorus for Larix gmelinii trees. Acta Ecologica Sinica 34 (8), 1965, 2014

34. ABBAS M., EBELING A., OELMANN Y., PTACNIK R., ROSCHER C., WEIGELT A., WEISSER W.W., WILCKE W., HILLEBRAND $\mathrm{H}$. Biodiversity effects on plant stoichiometry. Plos one 8 (3), e58179, 2013.

35. ZAVIŠIC A., POLLE A. Dynamics of phosphorus nutrition, allocation and growth of young beech (Fagus sylvatica L.) trees in P-rich and P-poor forest soil. Tree Physiology 38, 1, 2018.

36. MICHAELS A.F. The ratios of life. Science 300, 906, 2003.

37. NIU D.C., DONG X.Y., FU H. Seasonal dynamics of carbon, nitrogen and phosphorus stoichiometry in Stipa bungeana. Pratacultural Science 28 (6), 915, 2011.

38. CHEN C., WANG G.J., ZHAO Y., ZHOU G.X., LI L., GAO J.Q. Seasonal dynamics and allometric growth relationships of $\mathrm{C}, \mathrm{N}$, and $\mathrm{P}$ stoichiometry in the organs of Cunninghamia lanceolata from Huitong. Acta Ecologica Sinica 36 (23), 7614, 2016.

39. LIU J.G., LIU W.G., ZHU Y.Y., NURLAN M. Seasonal variation of $\mathrm{N}$ and $\mathrm{P}$ stoichiometric characteristics in leaves of certain ephemeral plants in the Gurbantunggut Desert, China. Chinese Bulletin of Botany 52 (23), 756, 2017.

40. LI H.L., GONG L., HONG Y. Seasonal variations in $\mathrm{C}, \mathrm{N}$, and $\mathrm{P}$ stoichiometry of root, stems, and leaves of Phragmites australis in the Keriya Oasis, Xinjiang, China. Acta Ecologica Sinica 36 (20), 6547, 2016.
41. LIU F.D., LIU Y.H., WANG G.M., SONG Y., LIU Q., LI D.S., MAO P.L., ZHANG H. Seasonal variations of C: N: $\mathrm{P}$ stoichiometry and their trade-offs in different organs of Suaeda salsa in coastal wetland of Yellow River Delta, China. Plos one 10 (9), e 0138169, 2015.

42. LI Z., HAN L., LIU Y.H., AN S.Q., LENG X. C, N and $\mathrm{P}$ stoichiometric characteristics in leaves of Suaeda salsa during different growth phase in coastal wetlands of China. Chinese Journal of Plant Ecology 36 (10), 1054, 2012.

43. NIU D.C., LI Q., JIANG S.G., CHANG P.J., FU H. Seasonal variations of leaf C:N:P stoichiometry of six shrubs in desert of China's Alxa Plateau. Chinese Journal of Plant Ecology 37 (4), 317, 2013.

44. LI H.L., MJ C.C., XU F.L., WANG W.L., MA L.H., NIU R.L., GAO X., LI X.X., ZHANG P., MA X., CHEN H.K. Seasonal variations in carbon, nitrogen and phosphorus concentrations and C:N:P stoichiometry in different organs of a Larix principis-rupprechtii Mayr. plantation in the Qinling Mountains, China. Plos one 12 (9), e0185163, 2017.

45. ZHAO Y.F., XU F.L., WANG W.L., WANG L.L., WANG G.X., SUN P.Y., BAI X.F. Seasonal variation in contents of $\mathrm{C}, \mathrm{N}$ and $\mathrm{P}$ and stoichiometry characteristics in fine roots, stems and needles of Larix principis-rupprechtii. Chinese Bulletin of Botany 49 (5), 560, 2014.

46. ZHOU P., GENG Y., MA W.H., HE J.S. Linkages of functional traits among plant organs in the dominant species of the Inner Mongolia grassland, China. Chinese Journal of Plant Ecology 34 (1), 7, 2010.

47. ÅGREN G.I. The C: N: P stoichiometry of autotrophstheory and observations. Ecology Letters 7 (3), 185, 2004.

48. HAN W.X., TANG L.Y., CHEN Y.H., FANG J.Y. Relationship between the relative limitation and resorption efficiency of nitrogen vs phosphorus in woody plants. Plos one 8 (12), e83366, 2013.

49. TESSIER J.T, RAYNAL D.J. Use of nitrogen to phosphorus ratios in plant tissue as an indicator of nutrient limitation and nitrogen saturation. Journal of Applied Ecology 40, 523, 2003.

50. CHEN F.S., NIKLAS K.J., ZENG D.H. Important foliar traits depend on species-grouping: analysis of a remnant temperate forest at the Keerqin Sandy Lands, China. Plant and soil 340, 337, 2011.

51. LIN H., ZHEN J.D., YUAN Y.Y., DONG H.Z., ZHANG S.L., ZHANG S.X. Applying foliar stoichiometric traits of plants to determine fertilization for a mixed pine-oak stand in the Qinling Mountains, China. PeerJ 6, e4628, 2018.

52. YU Y.H., CHI Y.K. Ecological stoichiometric characteristics of soil at different depths in a karst plateau mountain area of China. Polish Journal of Environmental Studies 29 (1), 1, 2020. DOI: 10.15244/pjoes/102781

53. ZHANG M.Y., ZHANG W.Y., BAI S.H., NIU Y., HU D.N., JI H.R., XU Z.H. Minor increases in Phyllostachys edulis (Moso bamboo) biomass despite evident alterations of soil bacterial community structure after phosphorus fertilization alone: Based on field studies at different altitudes. Forest Ecology and Management 451, 117561, 2019.

54. YU Z.P., WANG M.H., HUANG Z.Q, LIN T C., VADEBONCOEUR M.A., SEARLE E.B., CHEN H.Y.H. Temporal changes in soil C-N-P stoichiometry over the past 60 years across subtropical China. Global Change Biology 24, 1308, 2018.

55. BAI X.F., XU F.L., WANG W.L., ZHAO Y.F., WANG L.L., SUN P.Y. Ecological stoichiometry of soil carbon, nitrogen and phosphorus in a Larix principis-rupprechtii 
plantation. Science of Soil and Water Conservation 13(6), 68, 2015.

56. MIAO P., XIE W.X., YU D.S., CHEN J.L., GONG J. Vertical distribution and seasonal variation of nitrogen, phosphorus element in Spartina alterniflora wetland of Jiaozhou Bay, Shandong, China. Chinese Journal of Applied Ecology 28 (5), 1533, 2017.

57. BLUME E., BISCHOFF M., REICHERT J.M., MOORMAN T., KONOPKA A.,TURCO R F. Surface and subsurface microbial biomass, community structure and metabolic activity as a function of soil depth and season. Applied Soil Ecology 20, 171, 2002.

58. TIAN H.Q., CHEN G.S., ZHANG C., MELILLO J.M. HALL C.A.S. Pattern and variation of C: N: $\mathrm{P}$ ratios in China's soils: a synthesis of observational data. Biogeochemistry 98, 139, 2010.

59. CLEVELAND C.C., LIPTZIN D. C: N: P stoichiometry in soil: is there a "Redfield ratio" for the microbial biomass? Biogeochemistry 85, 235, 2007.

60. ZHANG K., SU Y.Z., WANG T., LIU T.N. Soil stoichiometry characteristics of Haloxylon ammodendron with different plantation age in the desert-oasis ecotone, northern China. Acta Ecologica Sinica 36 (11), 3235, 2016.

61. REICH P.B., WALTERS M.B., ELLSWORTH D.S. From tropics to tundra: global convergence in plant functioning. Proceedings of the National Academy of Sciences of the United States of America 94 (25), 13730, 1997.

62. ZHOU H.Y., WU Q., CHEN M.Y., KUANG W., CHANG L.L., HU Q.W. C, N and P stoichiometry in different organs of Vitex rotundifolia in a Poyang Lake desertification hill. Chinese Journal of Plant Ecology 41 (4), 461, 2017.

63. LIU W.D., SU J.R., LI S.F., ZHANG Z.J., LI Z.W. Stoichiometry study of $\mathrm{C}, \mathrm{N}$ and $\mathrm{P}$ in plant and soil at different successional stages of monsoon evergreen broadleaved forest in Pu'er, Yunnan Province. Acta Ecologica Sinica 30 (23), 6581, 2010.

64. YAN K., FU D.G., HE F., DUAN C.Q. Leaf nutrient stoichiometry of plants in the phosphorus-enriched soils of the Lake Dianchi watershed, southwestern China. Chinese Journal of Plant Ecology 35 (4), 353, 2011.

65. WANG L.L., ZHAO G.X., LI M., ZHANG M.T., ZHANG L.F., ZHANG X.F., AN L.Z., XU S.J. C:N:P stoichiometry and leaf traits of halophytes in an arid saline environment, northwest China. Plos one 10 (3), e0119935, 2015.

66. WANG W.Q., XU L.L., ZENG C.S., TONG C., ZHANG L.H. Carbon, nitrogen and phosphorus ecological stoichiometric ratios among live plant-litter-soil systems in estuarine wetland. Acta Ecologica Sinica 31 (23), 7119, 2011.

67. CHEN X.C., WANG R.Q., CAO Q.Q, ZHANG H.J, GE X.L, LIU J. The Relationship between the Distribution of Invasive Plant Alternanthera philoxeroides and Soil Properties is Scale-Dependent. Polish Journal of Environmental Studies 24 (5), 1931, 2015. DOI: 10.15244/ pjoes $/ 43367$

68. HEYBURN J., MCKENZIE P., CRAWLEY M.J., FORNARA D.A. Effects of grassland management on plant $\mathrm{C}: \mathrm{N}: \mathrm{P}$ stoichiometry: Implications for soil element cycling and storage. Ecosphere 8, 1, 2017.

69. HE J.S., HAN X.G. Ecological stoichiometry: Searching for unifying principles from individuals to ecosystems. Chinese Journal of Plant Ecology 34 (1), 2, 2010.

70. ZENG Z.X., WANG K.L., LIU X.L., ZENG F.P., SONG T.Q., PENG W.X., ZHANG H., DU H. Stoichiometric characteristics of plants, litter and soils in karst plant communities of northwest Guangxi. Chinese Journal of Plant Ecology 39 (7), 682, 2015.

71. WANG Z.F., ZHENG F.L. C, N and $\mathrm{P}$ stoichiometric characteristics of Pinus tabulaeformis plantation in the Ziwuling region of Loess Plateau. Acta Ecologica Sinica 38 (19), 6870, 2018.

72. CHEN A.N., WANG G.J., CHEN C., WANG S.Y., WANG W.J. Variation in the $\mathrm{N}$ and $\mathrm{P}$ stoichiometry of leafroot- soil during stand development in a Cunninghamia lanceolata plantation in subtropical China. Acta Ecologica Sinica 38 (11), 4027, 2018. 